Січкоріз O.C.

\title{
Результати опитування викладачів закладів вищої медичної освіти щодо тематичного удосконалення лікарів новітнім шляхом мультидисциплінарних циклів
}

\author{
Львівський національний медичний університет імені Данила Галицького, м. Львів, Україна \\ sichkorizoye@gmail.com
}

\author{
Сичкориз О.Е. \\ Результаты опроса преподавателей учреждений \\ высшего медицинского образования относительно \\ тематического усовершенствования врачей новейшим \\ путем мультидисциплинарных циклов \\ Львовский национальный медицинский университет \\ имени Данила Галицкого, г. Львов, Украина
}

Sichkoriz O.E.

Results of survey of lecturers of higher medical education institutions on thematic advanced training of doctors with the help of multidisciplinary cycles

Danylo Halytsky Lviv National medical university, Lviv, Ukraine

\section{Вступ}

Реформування системи охорони здоров'я України пов'язане не лише зі структурними i фінансовоекономічними змінами, але i 3 забезпеченням кваліфікованими кадрами, що ставить перед системою вищої медичної освіти особливі вимоги до підготовки лікарів [6].

Лікар, як ключовий фахівець процесу реформування медичної галузі повинен щодня кваліфіковано і ефективно вирішувати різноманітні медико-соціальні, психологопедагогічні, юридично-правові та інші завдання, що стосуються його пацієнтів. Виходячи зі значення та ролі лікарів у збереженні здоров'я населення, сучасних вимог щодо якості їх професійної підготовки, необхідно впроваджувати у навчальний процес принципи доказової медицини, розвивати моральні якості та професійну культуру лікарів, формувати відповідні професійні навички та компетенції $[1,5]$. Безперервний професійний розвиток лікаря $\epsilon$ сьогодні пріоритетним напрямком розвитку медичної освітньої галузі України у процесі іiї інтеграції у світовий та Європейський простір $\mathrm{i}$ розглядається як важлива умова підвищення якості надання медичної допомоги населенню [2-4].

Навчальний процес в системі післядипломної медичної освіти повинен будуватися на засадах, що відповідають державним стандартам медичної галузі. Це, в свою чергу, вимагає розробки та впровадження нових інноваційних форм курсів тематичного удосконалення лікарів. Тому метою нашого дослідження було сформувати рекомендації для впровадження та удосконалення мультидисциплінарних циклів тематичного удосконалення лікарів 3 актуальних питань сучасної охорони здоров'я на курсах тематичного удосконалення лікарів.

\section{Матеріали та методи}

3 метою реалізації мети дослідження нами використано як основний метод збору соціальнопсихологічної інформації метод опитування у вигляді стандартизованого (формалізованого) інтерв'ю, яке складалося 3 двох етапів. На першому етапі були опитані науково-педагогічні працівники кафедр, якими проводяться заняття на основі такої інноваційної форми, як мультидисциплінарний підхід проведення курсів тематичного удосконалення лікарів. На другому етапі опитуванню підлягали науково-педагогічні працівники, які працюють за звичайною схемою проведення курсів тематичного удосконалення лікарів. Разом було опитано 307 осіб 3 числа викладачів ЛНМУ імені Данила Галицького.

Час реалізації опитування: січень 2018 року, травень 2019 року.

На першому етапі в опитуванні взяло участь 163 науково-педагогічних працівників, які працюють на основі мультидисциплінарного підходу проведення курсів тематичного удосконалення. Розподіл за статтю склав: $39,00 \%$ - чоловіки, 61,00\% - жінки. Вікова характеристика респондентів: $25-30$ років - 3,97\%, 31-40 років $-25,40 \%$, $41-50 \%-34,13 \%, 51-60$ років - 25,40\%, 61 і більше - 9,52\% (1,59\% не дали відповіді на питання). Опитувані мали різні спеціальності. Зокрема, лікувальна справа: 39,68\% терапевтичний профіль, 21,43\% - хірургічний профіль; педіатричний профіль: 26,19\% - терапевтичний профіль, $10,32 \%$ - хірургічний профіль (2,38\% не дали відповіді на питання). Респонденти мали наступний стаж викладацької роботи: до 5 років - 3,97\%, 6-10 років - 21,43\%, 1115 років - 26,98\%, 16-20 років - $18,25 \%$, більше 20 років 24,60\% (4,76\% не дали відповіді на питання). 
На другому етапі було опитано 144 респонденти, які працюють за традиційною моделлю проведення курсів тематичного удосконалення.

Розподіл за статтю склав: $36,00 \%$ - чоловіки, $64,00 \%$ - жінки. Вікова характеристика респондентів: 2530 років $-6,25 \%, 31-40$ років $-29,17 \%, 41-50 \%-16,67 \%$, 51-60 років - 28,47\%, 61 і більше - 19,44\%. Опитувані мали такі спеціальності. Лікувальна справа: 42,36\% терапевтичний профіль, 34,03\% - хірургічний профіль; педіатричний профіль: $16,94 \%$ - терапевтичний профіль, $2,08 \%$ - хірургічний профіль $(4,59 \%$ не дали відповідь на питання). Респонденти мали такий стаж викладацької роботи: до 5 років - 11,11\%, 6-10 років - 19,44\%, 11 15 років - $23,61 \%, 16-20$ років - $15,97 \%$, більше 20 років $25,00 \%$ (4,86\% не дали відповіді на питання).

Статистичне опрацювання отриманих результатів здійснено шляхом розрахунку відносних величин. Порівняння часток проведено 3 використанням методу ксі-квадрат Фішера.

\section{Результати дослідження та їх обговорення}

Розвиток компетенцій та компетентності лікарів, зростання їх професіоналізму у вирішальній мірі залежить від наукового та методичного забезпечення післядипломної освіти.

Аналіз відповідей науково-педагогічних працівників, які працюють за інноваційним мультидисциплінарним підходом проведення тематичного удосконалення лікарів показує, що майже всі опитані, а це 94,4\% вважають за доцільне впровадження такої інноваційної форми проведення курсів ТУ лікарів.

Дещо менше науково-педагогічних працівників $(82,64 \%)$, які проводять курси тематичного удосконалення лікарів за попередньою схемою, вважають доцільним введення такої інновації, хоча категорично не заперечують i частина їх $(11,81 \%)$ ще не визначилась зі своїм ставленням.

Для впровадження інновацій в освітній сфері важливу роль відіграє особиста готовність до реалізації нових завдань. Як виявилось, переважна більшість викладачів - 92,06\%, які вже працюють за новітньою схемою курсів ТУ вважають себе готовими до реалізації нових освітніх завдань.

Готовність до впровадження інновацій серед науково-педагогічних працівників, котрі працюють за традиційною системою викладання нижча, і становить $72,22 \%$ ( $<0,05)$. Аналіз відповідей з-поміж викладачів, які неготові до інновацій засвідчив, що причиною неготовності вони вважають недостатню поінформованість щодо організації такого навчання 23,61\% та брак сучасної наукової інформації. Оскільки на це питання не дало відповідь більшість опитаних - 69,94\%, причиною, на нашу думку, може бути як небажання змінюватись особисто, так і страх змін взагалі (рис. 1).

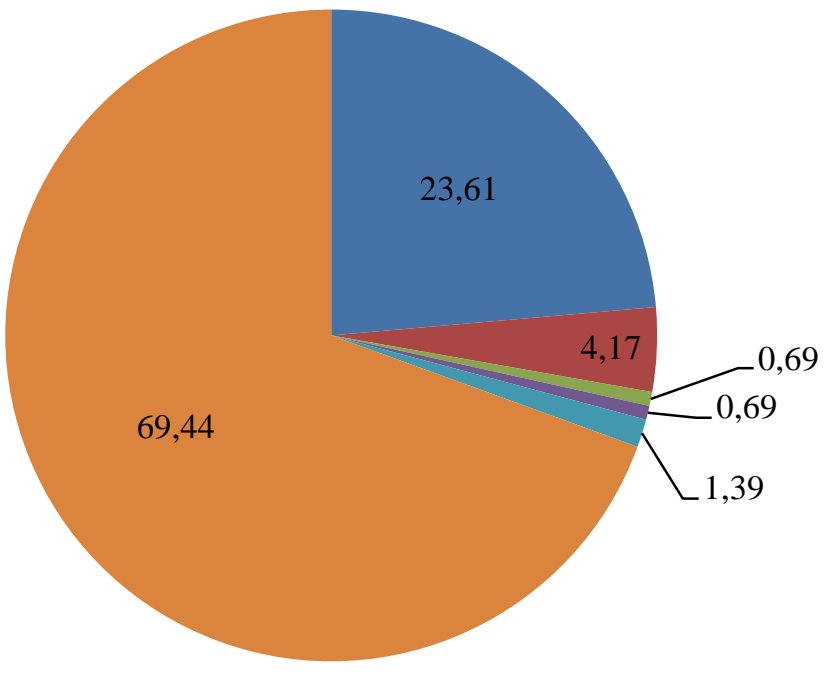

- Недостатньо інформації

- Брак сучасної наукової інформації

- Не володію в достатній мірі

— Не готовий психологічно

- Достатньо своєї роботи

- Нема відповіді

Рис. 1. Розподіл причин, через які науково-педагогічні працівники, котрі працюють за традиційною системою викладання, неготові до впровадження інновацій в освітній сфері (\% від тих, хто не готовий до впровадження)

Виконання нових освітніх завдань вимагає допомоги та підтримки зі сторони провідної кафедри, де працюють науково-педагогічні працівники та/або суміжних кафедр. Викладачі, які вже працюють за мультидисциплінарним підходом проведення курсів ТУ лікарів найбільше потребують обміну досвідом в новій парадигмі проведення занять. На це вказало 57,94\% опитаних. Окрім цього, вони потребують допомоги в пошуках новітньої інформації - 39,68\%, методичних рекомендацій щодо проведення таких інноваційних занять - 34,13\% та організації короткострокових семінарів 3 методики проведення занять для викладачів на постійно діючій основі - 27,78\% (рис. 2).

Рейтинг потреб науково-педагогічних працівників, які працюють за традиційною системою проведення курсів тематичного удосконалення лікарів розподілився наступним чином: короткострокові семінари 3 методики проведення занять - 42,36\%, обмін досвідом щодо 
проведення занять - 40,28\%, методичні рекомендації щодо проведення занять - 26,39\% (рис. 3). Слід зазначити, що більше половини викладачів, які вже працюють за мультидисциплінарним підходом надають перевагу обміну досвідом щодо проведення занять (різниця становить $17,66 \%$, p<0,05).

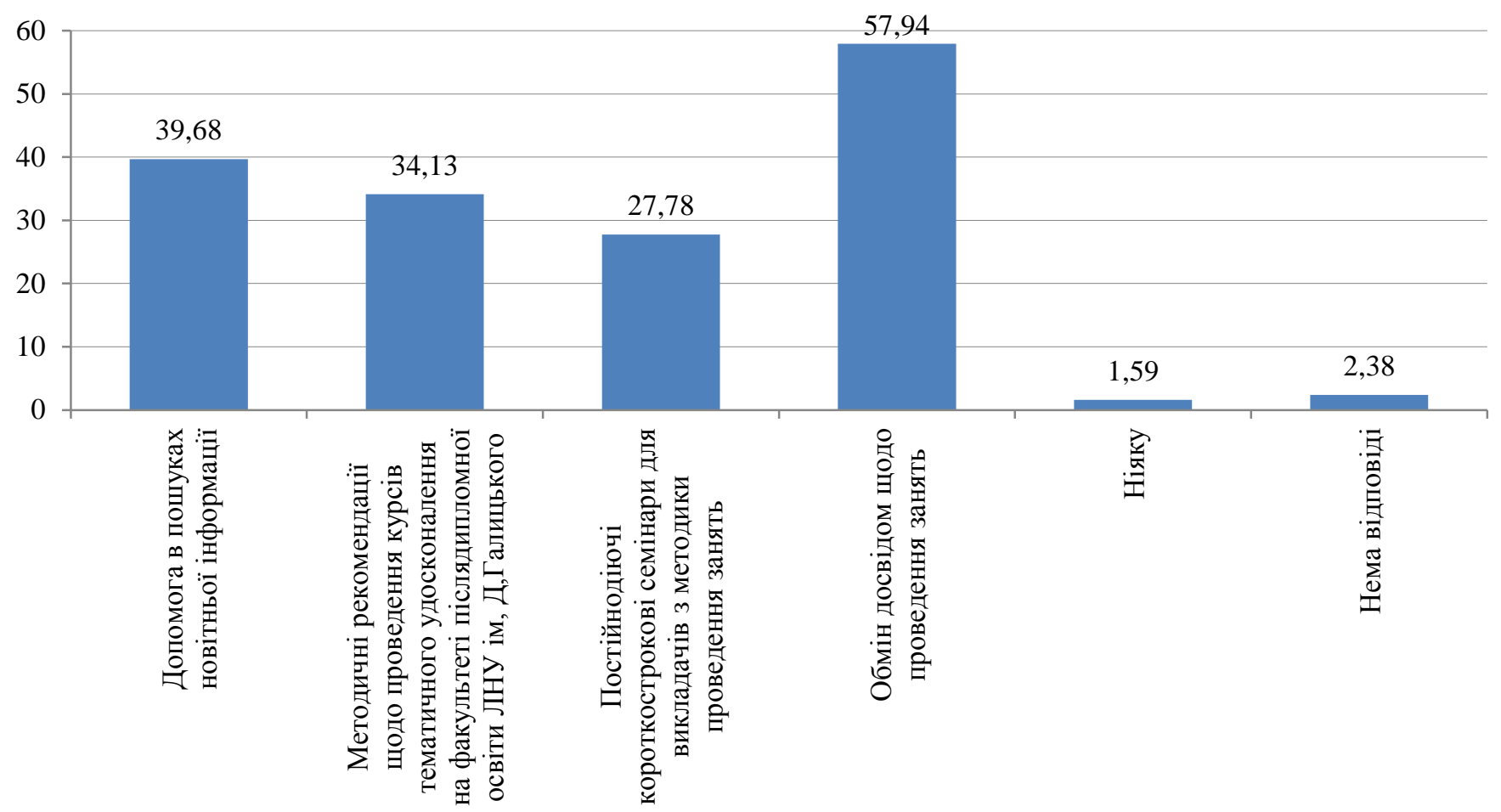

Рис. 2. Допомога, яку очікують (потребують) від кафедри працівники, які працюють за інноваційною схемою викладання, для проведення занять за мультидисциплінарним підходом (випадки на 100 опитаних)* *кількість відповідей на питання не обмежувалась

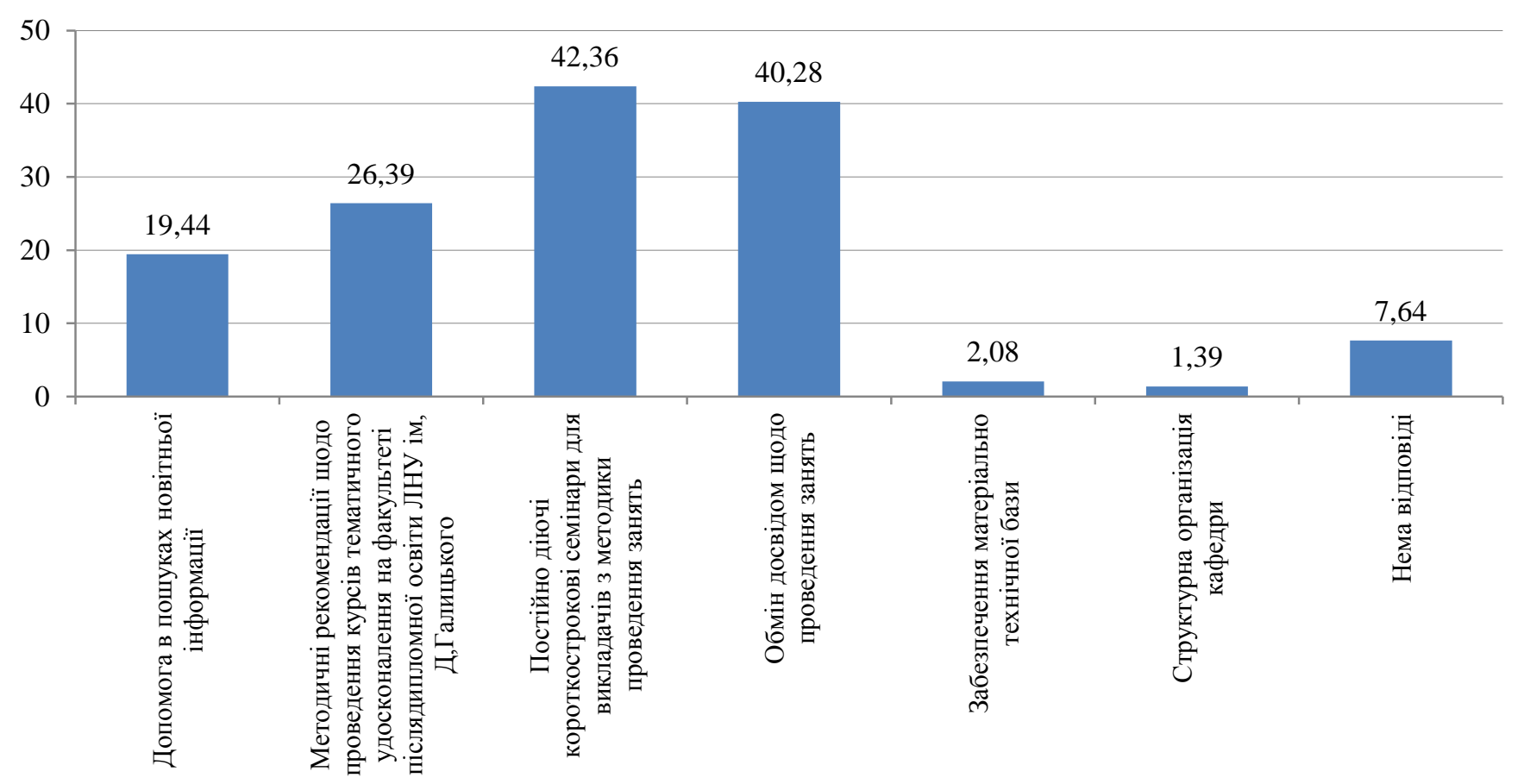

Рис. 3. Допомога, яку очікують (потребують) від кафедри працівники, які працюють за традиційною схемою викладання, для проведення занять за мультидисциплінарним підходом (випадки на 100 опитаних)* *кількість відповідей на питання не обмежувалась 
Стосовно очікуваної допомоги 3 боку деканату факультету післядипломної освіти, думки зазначених категорій науково-педагогічних працівників розділились. Викладачі, які вже працюють на основі мультидисциплінарного підходу мають більш практичні побажання. Серед них можемо виділити організацію постійного місця проведення занять, організацію праці викладача, надання методичних рекомендацій.

Натомість серед відповідей викладачів, які працюють за традиційною системою, можна зустріти побажання організувати закордонне стажування (4,33\%), надання сучасного обладнання $(8,06 \%)$, набуття практичних навичок $(17,36 \%)$, хоча практичні навички формуються в процесі практичної діяльності, методичне забезпечення занять $(37,14 \%)$. Це може свідчити про дещо споживацький підхід до впровадження мультдисциплінарної системи навчання та приховане бажання уникнути власної відповідальності за результати праці.

Також спостерігається різниця у відповідях стосовно часу, який необхідний для підготовки проведення якісних занять зі слухачами. Науковопедагогічні працівники 3 інноваційним досвідом викладання потребують від 1 місяця $(43,65 \%)$ до 23 місяців (47,62\% опитаних).

Частина науково-педагогічних працівників, які працюють за традиційною системою викладання, вважають, що їм необхідно для підготовки до 6 місяців (29,17\% проти 3,17\%), що може свідчити про стереотипне сприйняття навчального процесу, небажання змін і слабку мотивацію.

Дещо різняться думки респондентів стосовно форм контролю, які найбільш доцільно застосовувати для слухачів після навчання на мультидисциплінарному циклі тематичного удосконалення. Так, викладачі 3 досвідом роботи в інноваційній системі перевагу надають письмовому опитуванню - 37,30\% проти 20,83\% ( $<00,05)$, тестуванню на паперових носіях - 38,89\% проти 29,86\% ( $>>0,05)$, проведенню колоквіумів - 33,33\% проти $10,42 \%$ $(\mathrm{p}<0,05)$. Натомість викладачі традиційної системи навчання перевагу надали б тестуванню на комп'ютері $57,64 \%$ проти $37,30 \%(\mathrm{p}<0,05)$.

Цікавими $€$ відповіді науково-педагогічних працівників, які викладали в мультидисциплінарному підході щодо труднощів при проведення занять. Основні труднощі стосуються організаційних моментів: недосконала система організації занять - 20,63\%, відсутність методичного забезпечення - 15,08\%, недостатньо необхідної фахової літератури - 14,29\%, відсутність необхідних засобів для проведення занять $13,49 \%$ (рис. 4 ).

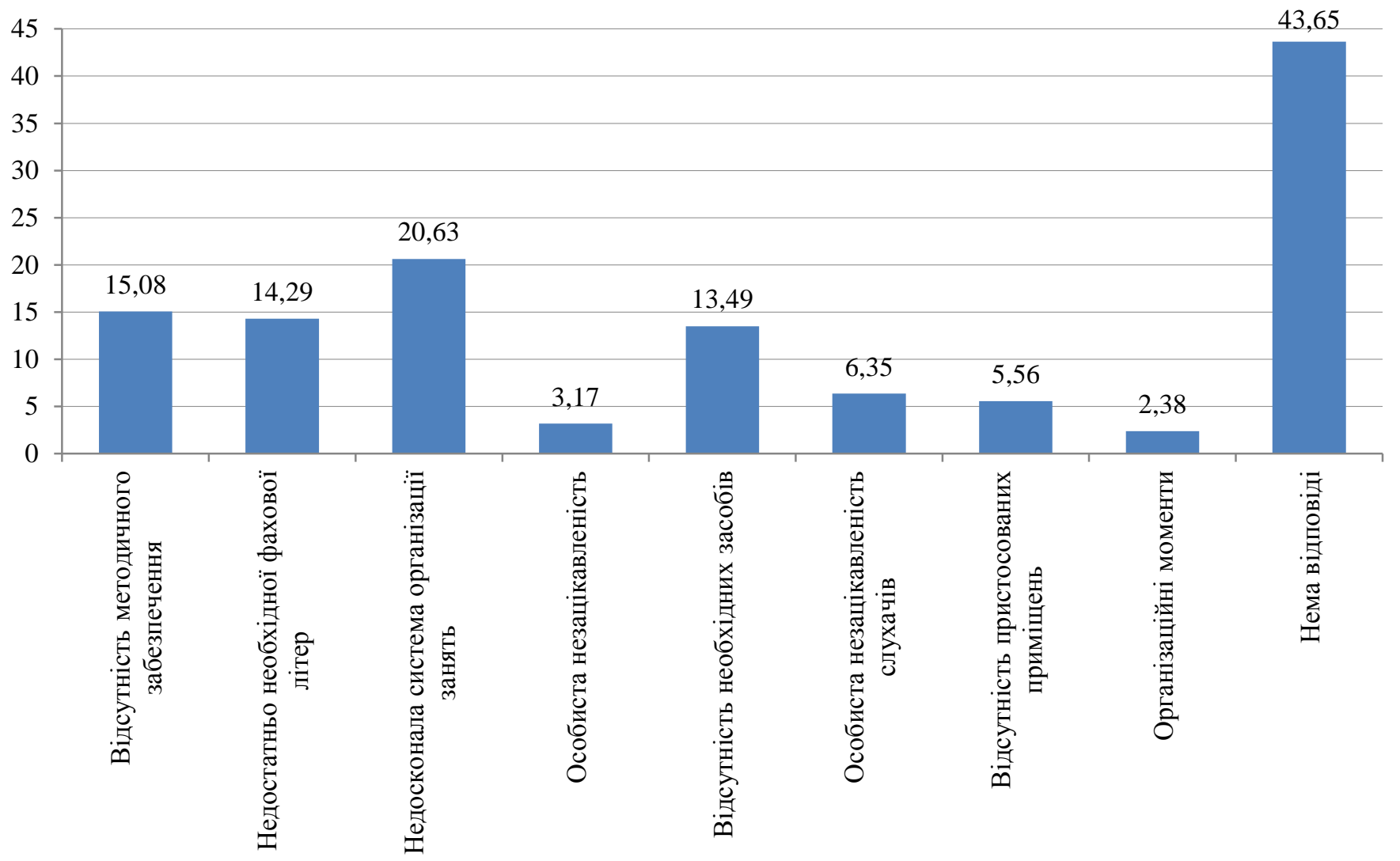

Рис. 4. Труднощі, які виникали у викладачів при проведенні занять на мультидисциплінарному циклі тематичного удосконалення (\%) 
На основі відповідей на вказане питання можемо припустити, що викладання на мультидисциплінарному циклі тематичного удосконалення сприяє розвитку у науково-педагогічних працівників лідерських якостей та сприяє покращенню їх соціальної адаптованості.

Більшість викладачів на мультидисциплінарному циклі тематичного удосконалення, а це становить 76,19\% задоволені переліком суміжних дисциплін. 3-поміж науково-педагогічних працівників традиційного викладання задоволені запропонованим переліком суміжних дисциплін трохи більше половини 54,17\% $(\mathrm{p}<0,05)$.

Ми пропонували, в ході реалізації дослідження, науково-педагогічним працівникам скласти власний перелік суміжних дисциплін для викладання на мультидисциплінарному циклі ТУ лікарів. Серед відповідей викладачів які вже працюють за інноваційним підходом та викладачів, які працюють за традиційною схемою викладання не можна виділити дисципліни, що вимагають приділення особливої уваги.

Можемо дещо виділити побажання більше часу приділити вивченню нових тенденцій в лікуванні онкологічних захворювань $(11,90 \%)$ та анестезіології $(10,32 \%)$ - 3 результатів викладачів, які вже працюють на основі мультидисциплінарного підходу проведення ТУ.

Викладачі, які працюють за традиційною схемою вважають, що трішки більше часу потрібно приділити навчальному матеріалу стосовно інфекційних захворювань - 11,11\%. Однак те, що більше половини респондентів не дали відповіді на пропоноване питання може свідчити, що їх задовольняє існуючий перелік суміжних дисциплін.

Важливим, на нашу думку, при плануванні занять на мультидисциплінарному циклі ТУ лікарів $є$ співвідношення занять 3 основного фаху та суміжних дисциплін.

Половина науково-педагогічних працівників 3 досвідом викладання на мультидисциплінарному циклі ТУ вважають, що оптимальним є співвідношення 70\% навчального матеріалу за фахом слухачів, 10\% - клінічна імунологія, $10 \%$ - медичне право, $10 \%$ - клінічна фармація. Менша частина викладачів - 16,67\% - вважать, що частка навчальних дисциплін має бути однакова - по $25 \%$, і ще менша частина - 14,29\% - вважають, що основний фах повинен займати $90 \%$ навчального навантаження, а частка суміжних дисциплін повинна становити третину часу, що залишився.

Такої ж думки науково-педагогічні працівники без досвіду викладання за інноваційною схемою щодо розподілу навчального навантаження: 70\% навчального матеріалу за фахом слухачів, 10\% - клінічна імунологія, $10 \%$ - медичне право, $10 \%$ - клінічна фармація притримується $54,86 \%$ викладачів, які працюють за традиційною схемою викладання. Однак більше чверті опитаних $(26,39 \%)$ висловили пропозицію, що години основного фаху повинні становити $10 \%$, а по $30 \%$ часу навчання на курсах повинні займати суміжні дисципліни: клінічна імунологія, медичне право, клінічна фармація.
Для організації навчання на мультидисциплінарному циклі ТУ важливо визначитись 3 категоріями, для яких слід проводити таке навчання. Більше половини викладачів - 65,08\% - вважають, що таке навчання повинно проводитись для лікарів зі стажем практичної роботи.

Серед тих, хто так вважає, 7,30\% переконані, що це мають бути лікарі зі стажем роботи до 5 років (без категорії), 45,10\% - зі стажем роботи 6-10 років, $34,10 \%$ зі стажем роботи $11-15$ років, $11,12 \%$ - 16-20 років, $2,41 \%-21$ рік і більше.

Третина викладачів - 30,16\% - вважають, що це мають бути всі лікарі, які висловили бажання навчатись на мультидисциплінарному циклі ТУ.

Думка науково-педагогічних працівників, які викладають за традиційною системою навчання дещо відрізняється. Більшість - 73,61\% - вважає, що навчання на мультидисциплінарному циклі ТУ слід проводити для всіх категорій лікарів, беручи до уваги тільки їхнє бажання. П'ята частина - 20,83\% - висловили думку, що навчання на мультидисциплінарному циклі ТУ слід проводити тільки для лікарів зі стажем практичної діяльності.

\section{Перспективи подальших досліджень}

Мультидисциплінарний підхід на циклах тематичного удосконалення лікарів $є$ прогресивною формою післядипломної освіти на сучасному етапі, тому подальші дослідження слід зосередити на вивченні досвіду зарубіжних країн 3 даного питання для створення якісної навчально-методичної бази безперервної післядипломної освіти медичних фахівців.

\section{Висновки}

1. Результати медико-соціального дослідження науково-педагогічних працівників вказують на доцільність та своєчасність впровадження такої інноваційної форми тематичного удосконалення як мультидисциплінарне навчання.

2. Впровадження мультидисциплінарного навчання на курсах тематичного удосконалення лікарів вимагає доопрацювання організаційної складової обладнаних місць проведення занять, оптимізацію організації праці викладачів і допоміжного персоналу, побудову відповідного гнучкого розкладу занять, організацію відповідного часу науково-педагогічним працівникам на підготовку до проведення занять (35 місяців).

3. Навчально-методична складова таких циклів повинна передбачати: організацію постійно діючих короткострокових семінарів для науково-педагогічних працівників, метою яких $є$ підготовка робочих навчальних програм нового циклу тематичного удосконалення, методичних розробок для викладачів 3 методики проведення занять i слухачів (теми семінарських, практичних занять, самостійну роботу тощо); організацію 
вільного доступу до новітньої наукової інформації; впровадження внутрішньо кафедральних та міжкафедральних семінарів 3 обміну досвідом щодо проведення занять; проведення психологічних тренінгів 3 метою формування психологічної та особистісної готовності науково-педагогічних працівників до інноваційної діяльності та формування в них лідерських якостей.

4. На основі проведеного дослідження ми можемо представити нову модель реалізації та впровадження такої інноваційної діяльності, як мультидисциплінарне навчання. Отримувачі освітніх послуг - лікарі зі стажем практичної стаціонарної діяльності від 5 до 20 років, які володіють інформаційно-комп'ютерними технологіями, працюють в медичних закладах районного, міського та обласного рівня, обласного центру; надавачі освітніх послуг - науково-педагогічні працівники кафедри за фахом, кафедр клінічної імунології, кафедри медичного права, кафедри клінічної фармації, які володіють такими рисами як професіоналізм, постійна потреба в самоосвіті, інноваційний стиль мислення, знання 3 методики викладання, знання з психології, мають якості лідера, соціально адаптовані і соціально активні.

5. 3 метою визначення якості навчання на мультидисциплінарному циклі тематичного удосконалення найбільш доцільними $є$ наступні форми контролю: колоквіуми, тестування на паперових носіях i комп'ютері, семінари, усні та письмові опитування, підготовка рефератів.

6. Досвід проведення мультидисциплінарних циклів тематичного удосконалення та вивчення думки різного контингенту слухачів дозволяє впровадження такого типу навчання в стандартах вечірньої та дистанційної форм навчання, а також курсів вихідного дня.

\section{Література}

1. Гутор Т. Г. Система моніторингу здоров'я на рівні первинної медико-санітарної допомоги як якісний механізм переорієнтації роботи лікарів на організацію профілактичних заходів. Україна. Здоров'я нації. 2013; 3: 28-34.

2. Мисак 3. С. Аналіз смертності від злоякісних новоутворень як критерій оцінки демографічних втрат населення України. Вісник проблем біології і медицини. 2019; 4, Т. 2 (154): 348-352. doi:10.29254/2077-4214-2019-4-2154-348-352.

3. Пономаренко В. М., Зіменковський А. Б. Методологічні підходи до визначення індикаторів оцінки якості діяльності системи охорони здоров'я. Вісник соціальної гігієни та організації охорони здоров'я України. 2006; 2: 31-35.

4. Про затвердження Положення про систему безперервного професійного розвитку фахівців у сфері охорони здоров’я. Постанова Кабінету міністрів України від 28 березня 2018 р. № 302 (зі змінами). URL: https://zakon.rada.gov.ua/ laws/show/302-2018-\%d0\%bf.

5. Січкоріз О. Є., Гутор Т. Г., Ковальська О. Р., Римаренко К. П. Впровадження у процес навчання фахівців первинної ланки медичної допомоги Волинської області сучасних знань з інтегрованого ведення випадків гіпертензії та цукрового діабету. Вісник соціальної гігієни та організації охорони здоров'я України. $2019 ; 3$ (81): 103-108. doi:10.11603/1681-2786.2019.3.10601.

6. Трансформація системи. URL: https://moz.gov.ua/article/reform-plan/moz-ukraini-opriljudnilo-dlja-gromadskogoobgovorennja-strategiju-rozvitku-medichnoi-osviti.

\section{References}

1. Hutor T. H. Systema monitorynhu zdorovya na rivni pervynnoyi medyko-sanitarnoyi dopomohy yak yakisnyy mekhanizm pereoriyentatsiyi roboty likariv na orhanizatsiyu profilaktychnykh zakhodiv. Ukrayina. Zdorovya natsiyi. 2013; 3: 28-34.

2. Mysak Z. S. Analiz smertnosti vid zloyakisnykh novoutvoren yak kryteriy otsinky demohrafichnykh vtrat naselennya Ukrayiny. Visnyk problem biolohiyi i medytsyny. 2019; 4, T. 2 (154): 348-352. doi:10.29254/2077-4214-2019-4-2-154-348-352.

3. Ponomarenko V.M., Zimenkovskyy A.B. Metodolohichni pidkhody do vyznachennya indykatoriv otsinky yakosti diyalnosti systemy okhorony zdorovya. Visnyk sotsialnoyi hihiyeny ta orhanizatsiyi okhorony zdorovya Ukrayiny. 2006; 2: 31-35.

4. Pro zatverdzhennya Polozhennya pro systemu bezperervnoho profesiynoho rozvytku fakhivtsiv u sferi okhorony zdorovya. Postanova Kabinetu ministriv Ukrayiny vid 28 bereznya 2018r. № 302 (zi zminamy). URL: https://zakon.rada.gov.ua/ laws/show/302-2018-\%d0\%bf.

5. Sichkoriz O. YE., Hutor T. H., Kovalska O. R., Rymarenko K. P. Vprovadzhennya u protses navchannya fakhivtsiv pervynnoyi lanky medychnoyi dopomohy Volynskoyi oblasti suchasnykh znan z intehrovanoho vedennya vypadkiv hipertenziyi ta tsukrovoho diabetu. Visnyk sotsialnoyi hihiyeny ta orhanizatsiyi okhorony zdorovya Ukrayiny. $2019 ; 3$ (81): 103-108. doi:10.11603/1681-2786.2019.3.10601.

6. Transformatsiya systemy. URL: https://moz.gov.ua/article/reform-plan/moz-ukraini-opriljudnilo-dlja-gromadskogoobgovorennja-strategiju-rozvitku-medichnoi-osviti.

Дата надходження рукопису до редакції: 23.12.2019 р. 
Мета - сформувати рекомендації для впровадження та удосконалення мультидисциплінарних циклів тематичного удосконалення лікарів з актуальних питань сучасної охорони здоров’я на курсах тематичного удосконалення лікарів.

Матеріали та методи. Як основний метод збору соціально-психологічної інформації використано метод опитування у вигляді стандартизованого (формалізованого) інтерв'ю. Було опитано 307 осіб: 163 науково-педагогічних працівників факультету післядипломної освіти Львівського національного медичного університету імені Данила Галицького, які працюють на основі мультидисциплінарного підходу проведення курсів тематичного удосконалення та 144 респонденти, які працюють за традиційною моделлю проведення курсів тематичного удосконалення.

Результати. Результати проведеного дослідження засвідчують, що оптимальним є таке співвідношення занять 3 основного фаху та суміжних дисциплін: 70\% навчального матеріалу за фахом слухачів, $10 \%$ - клінічна імунологія, $10 \%$ - медичне право, 10\% - клінічна фармація. Впровадження мультидисциплінарного навчання на курсах тематичного удосконалення лікарів вимагає доопрацювання організаційної та навчально-методичної складової проведення таких занять. Оптимальними формами проведення занять є: мультимедійні презентації, демонстрації хворих, відеоматеріали, кейси, ситуативні, ділові ігри.

Висновки. Результати медико-соціального дослідження науково-педагогічних працівників вказують на доцільність та своєчасність впровадження такої інноваційної форми тематичного удосконалення як мультидисциплінарне навчання.

Ключові слова: післядипломна освіта, тематичне удосконалення лікарів, мультидисциплінарне навчання.

Цель - сформировать рекомендации для внедрения и усовершенствования мультидисциплинарных циклов тематического усовершенствования врачей по актуальным вопросам современного здравоохранения на курсах тематического усовершенствования врачей.

Материалы и методы. В качестве основного метода сбора социально-психологической информации использован метод опроса в виде стандартизированного (формализованного) интервью. Было опрошено 307 человек: 163 научнопедагогических работников факультета последипломного образования Львовского национального медицинского университета имени Даниила Галицкого, работающих на основе мультидисциплинарного подхода проведения курсов тематического усовершенствования и 144 респонденты, работающие по традиционной модели проведения курсов тематического усовершенствования.

Результаты. Результаты проведенного исследования свидетельствуют, что оптимальным является такое соотношение занятий с основной специальности и смежных дисциплин: 70\% учебного материала по специальности слушателей, $10 \%-$ клиническая иммунология, 10\% - медицинское право, 10\% - клиническая фармация. Внедрение мультидисциплинарного обучения на курсах тематического усовершенствования врачей требует доработки организационной и учебно-методической составляющей проведения таких занятий. Оптимальными формами проведения занятий являются: мультимедийные презентации, демонстрации больных, видеоматериалы, кейсы, ситуативные, деловые игры.

Выводы. Результаты медико-социального исследования научно-педагогических работников указывают на целесообразность и своевременность внедрения такой инновационной формы тематического усовершенствования как мультидисциплинарное обучения.

Ключевые слова: последипломное образование, тематическое усовершенствование врачей, мультидисциплинарное обучение.

The aim of the study is to form recommendations for the implementation and improvement of multidisciplinary cycles of thematic advanced training of doctors on topical issues of modern health care at the courses of thematic advanced training of doctors.

Materials and methods. A standardized (formalized) interview was used to collect social and psychological information. 307 individuals were interviewed: 163 scientific pedagogical staff members of the Faculty of Postgraduate Education of Danylo Halytsky Lviv National medical university, who work on the basis of multidisciplinary approach of thematic advanced training courses, and 144 respondents who work with the traditional model thematic advanced training courses.

Results. The results of the survey show that the following ratio of classes in the basic specialty and related disciplines is optimal: $70 \%$ of educational material in the specialty of the trainees, $10 \%$ of clinical immunology, $10 \%$ of medical law, $10 \%$ of clinical pharmacy. The introduction of multidisciplinary training in the courses of thematic advanced training of doctors requires refinement of the organizational and educational-methodical component of conducting such classes. The best forms of training are: multimedia presentations, demonstrations of patients, videos, cases, situational, business games.

Conclusions. The results of medical and social survey of scientific pedagogical staff indicate the feasibility and timeliness of the introduction of such innovative form of thematic advanced training as multidisciplinary study.

Key words: postgraduate education, thematic advanced training, multidisciplinary study.

\section{Відомості про автора}

Січкоріз Орест Свгенович - кандидат медичних наук, доцент кафедри дитячих інфекційних хвороб, декан факультету післядипломної освіти Львівського національного медичного університету імені Данила Галицького; 79010, м. Львів, вул. Пекарська, 69.

+380 (32) 276-93-74, sichkorizoye@ @mail.com, ORCID 0000-0002-2768-8592. 